\title{
Development of Medicinal Plant CultureThrough Empowerment of Entrepreneur
}

\author{
D. Mulyono ${ }^{1, *}$, D. Pinardi ${ }^{1}$, and A. Jufri ${ }^{1}$ \\ ${ }^{1}$ Researchers of Center for Agricultural Production Technology, The Agency for the Assessment and Application of \\ Technology, Laptiab Building, Puspiptek, South Tangerang, Indonesia 15314 \\ *Corresponding author, Email: darumulyono@yahoo.com
}

\begin{abstract}
The objectives of the assessment is to increase the development of more widespread cultivation of medicinal plant and empowering the economic comunity. The assessment is an analytical descriptive with information and primary data was gathered through various methods such as audience with key informant and discussion. Secondary data was gathered through scientific publication review. At present Indonesia has around 9,600 species of medicinal plant which has bright business prospects. World Health Organization in 2014 recommended the use of medicinal herbs for the prevention and treatment of chronic, degenerative, and cancerous diseases. Therefore, the world demand of medicinal herbs continues to increase. However, the development of medicinal plant cultivation in Indonesia has not been able to develop properly. The main problem encountered is that there are still many farmers who are reluctant to cultivate these medicinal plants because product of medicinal plant market is classified in the "grey market' which is unclear of the buyer and the price standard. Therefore, the assessment is carried out to develop an entrepreneurship model in relation to the role as a bridge between the farmers of medicinal plants and the medicinal herb processing industry. The main actors in this model are farmers, entrepreneurs, and medicine herb processing industry. The results of the assessment indicate that the development of medicinal plants entrepreneurship needs to be supported by providing several access facilities to technology, access to information, access to capital, and access to market. The development of the entrepreneurship can shorten the trade chain of medicinal plants product market where it will lead to build profitably synergy among the entrepreneur, medicinal plant farmer and medicinal herbs processing industry. Furthermore it is hoped that it will become triggers to the cultivation of medicinal plants more widespread and sustainably.
\end{abstract}

Keywords: Medicinal, Plant, Cultivation, Farmer, Entrepreneur

\section{INTRODUCTION}

Indonesia is located in the tropics and has a very large biodiversity or mega diversity with various flora including various species of medicinal plants. It is estimated that currently in Indonesia there are around 9,600 species of medicinal plants that have the potential to be developed and have bright business prospects [1]. This is supported by a change in the lifestyle of a globalized society which known as back to nature. This change in lifestyle is not only related to people's food consumption patterns, but has also spread to other sectors including medicine. Globally, there has also been a change in the pattern of public medicine, from the use of chemical drugs to herbs medicines made from natural ingredients.

The World Health Organization (WHO) through the World Health Assembly in 2014 recommended the use of herbs medicines for the prevention and treatment of chronic, degenerative and cancer diseases. According to WHO, herbs medicine has been used continuously by many countries in the world [2]. It is estimated that around $80 \%$ of the world's population uses herbs medicine to maintain health and fitness [3].

Although the production of medicinal plants in Indonesia tends to increase, the problem encountered until now that is many farmers are reluctant to cultivate medicinal plants as the main source of their family income. This is because the cultivation of this medicinal plant is still categorized in a "gray area" it is mean that the market is not clear. If farmers cultivate medicinal plants, the products are still unclear who the buyers are and at what price standards. This is different if farmers cultivate food crops such as rice, corn, sugar cane, and others. Sellof agricultural food crops is much easier and the price standard are also relatively clear because the government 
has set a Government Purchase Price [4]. Therefore, farmers tend to cultivate food crops with a more definite income calculation that can be expected to meet the needs of their family, including planning to save money.

Currently, there is a gap between the supply produced by farmers or supply and the demand of medicinal plant production needed by herbs medicine industry or demand. The existence of a gap between supply and demand is especially in terms of demand which is much larger than the supply where it must be captured as a business opportunity that must be developed to empower the people's economy.

The Decree of the Indonesian Minister of Health No. 381/Menkes/SK/III/2007 implies guidelines for the development of medicinal plants[5]. However, the policy has not yet been followed by steps that encourage the development of medicinal plants cultivation. This is because the policy regarding herbs medicine has not been followed by a conceptual program and the lack of coordination amongs related sectors regarding medicinal plant development programs [6]. It is further stated that almost all of herbs medicine industries, both small and large industries, have not provided technical guidance or training to medicinal plant farmers [7].

Given that in the future, the tendency of the community to consume herbs medicine is increasing, while productivity in the upstream area is felt to be relatively constant, and there are even some medicinal plant commodities whose production is decreasing. One of the programs in the development of medicinal plant cultivation is through the development of medicinal plant entrepreneurs. The development of medicinal plant entrepreneurship needs to be done more intensively so that the medicinal plant production trade chain becomes shorter which is expected to result in a higher selling price received by farmers. Therefore, currently the Agency for the Assessment and Application of Technology is conducting a study on the development of medicinal plant entrepreneurship as a model to be implemented so that there will be mutually beneficial synergies for medicinal plant farmers, entrepreneurs, andherbs medicine industry. The objective of the researchis to: (a). increase farmer participation in medicinal plant cultivation, (b). increasing the competitiveness of medicinal plant production in the national or global market, and (c). empowering the economy of the community, especially farmers.

\section{RESEARCH METHODS}

This research is a descriptive analytic study using secondary data collected through tracing various scientific publications and biopharmaca plant statistics from the Central Bureau of Statistics. To meet the data and information needs in compiling this entrepreneurship development model, discussions were held at the Agricultural Scientific Meeting Forum which was attended by several agricultural experts at the Agricultural Production Technology Center, Agency for the Assessment and Application of Technology, South
Tangerang on May 8, 2020. The data in this study were mainly obtained from cases that occurred in several districts in Central Java Province, which are centers for medicinal plant cultivation in Indonesia. The data forecasting analysis of the production of several medicinal plants was carried out by using the simple moving average method.

\section{RESEARCH FRAMEWORK}

In simple terms, the framework for developing of medicinal plant cultivation through entrepreneurship is described in Figure 1 below.

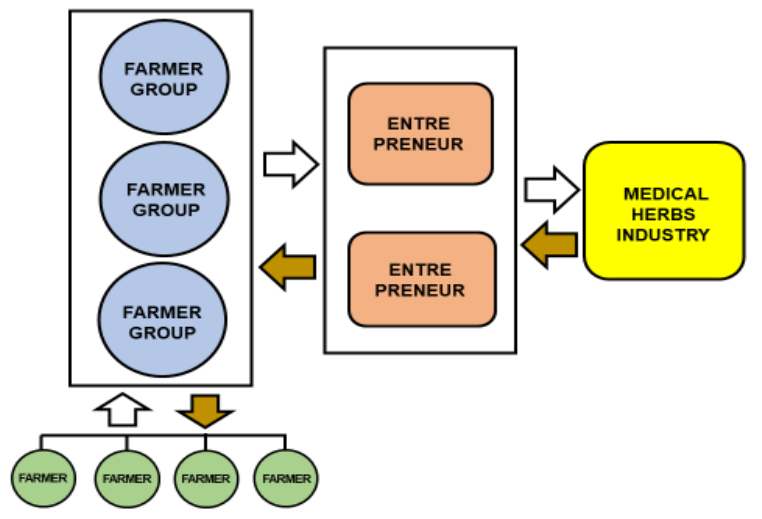

Figure 1. Framework for Entrepreneurship of Medicinal Plants

In the Figure 1, it can be seen that the entrepreneur has a very strategic dual role. On the one hand, entrepreneur plays a role in meeting the quality standards of medicinal plant production for the herbs medicine industryand on the other hand as a supervisor for the Farmers' Group so that the quality of medicinal plant production is in accordance with the standards required by the herbs medicine industry. Operationally this entrepreneur has the following duties: (a). marketing medicinal plant production directly to the herbs medicine industryso that the price level can be maintained high, and (b). provide facilities to farmers, especially business capital, production materials, technology and counseling to increase farmers' ability in cultivating medicinal plants.

Especially with the availability of adequate production materials for farmers, such as: superior medicinal plant seeds and fertilizers from entrepreneurs or assistance from the herbs medicine industry, the productivity and quality of medicinal plant production is expected to increase. Thus farmers will receive a reward from the sale of medicinal plant production at a high price because the high quality is in accordance with the requirements demanded by the herbs medicine industry. With the high level of selling price received by farmers, it is hoped that it will attract farmers to cultivate more intensive and broader medicinal plants. Therefore, to achieve success in fostering entrepreneurship, the local 
government must give support to provide facilitation by doing better cooperation with the herbs medicine industryto participate in coaching entrepreneurs and helping provide adequate of production facilities to farmers. Assistance for production facilities from entrepreneurs or the herbs medicine industry will be calculated with the yields sold by farmers. The development of entrepreneurship is expected to have an impact on the development of a strong people's economy.
In Indonesia, there are four potential medicinal plant commodities and their production continues to increase, namely: ginger, turmeric, cardamom, and galanga[8]. The increasing production of these medicinal plants is because the use of herbs medicines in recent years has tended to increase in line with the development of the herbs, pharmaceutical, cosmetic, food and beverage industry. In the last decade, the production of several potential medicinal plants in Indonesia has tended to increase, see at Table 1 and Figure 2.

\section{RESULTS AND DISCUSSION}

Table 1. Production of Several Medicinal Plants in Indonesia (tonnes)

\begin{tabular}{|c|c|c|c|c|}
\hline Year & Ginger & Tumeric & Cardamon & Galanga \\
\hline 2009 & 122,181 & 124,047 & 25,179 & 59,332 \\
\hline 2010 & 107,735 & 107,375 & 28,550 & 58,962 \\
\hline 2011 & 94,743 & 84,803 & 47,231 & 57,701 \\
\hline 2012 & 114,538 & 96,979 & 42,973 & 58,186 \\
\hline 2013 & 155,286 & 120,726 & 54,171 & 69,730 \\
\hline 2014 & 226,115 & 112,088 & 72,760 & 62,521 \\
\hline 2015 & 313,064 & 113,101 & 93,121 & 55,150 \\
\hline 2016 & 340,341 & 107,770 & 86,144 & 59,453 \\
\hline 2017 & 216,587 & 128,339 & 90,787 & 63,536 \\
\hline 2018 & 207,412 & 203,458 & 81,725 & 70,015 \\
\hline
\end{tabular}

Source: [8]

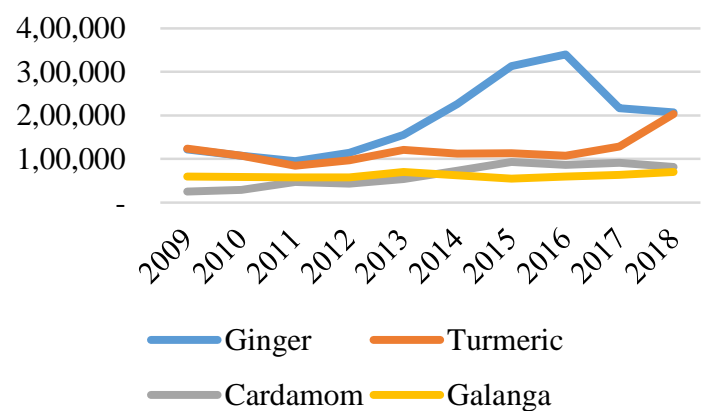

Figure 2. Several Medicinal Plant Production20092018 (ton)
It is estimated that the use of herbs medicines in Indonesia continues to increase considering the Indonesian culture that cannot be separated from consuming herbs medicines. The results of the forecasting analysis are estimated that in 2025, ginger production will reach 289,801 tons, turmeric will reach 206,824 tons, cardamom will reach 127,994 tons, and galanga will reach 82,069 tons, where the forecasting production volume successively every year can be seen in Table 2 below.

Tabel 2. Forecasting Production of Several Medicinal Plants in Indonesia (ton)

\begin{tabular}{|c|c|c|c|c|}
\hline Year & Ginger & Tumeric & Cardamon & Galanga \\
\hline 2019 & 217,563 & 203,935 & 87,134 & 71,622 \\
\hline 2020 & 228,212 & 204,414 & 92,901 & 73,266 \\
\hline 2021 & 239,382 & 204,894 & 99,050 & 74,947 \\
\hline 2022 & 251,098 & 205,375 & 105,606 & 76,668 \\
\hline 2023 & 263,388 & 205,857 & 112,595 & 78,427 \\
\hline 2024 & 276,279 & 206,340 & 120,048 & 80,227 \\
\hline 2025 & 289,801 & 206,824 & 127,994 & 82,069 \\
\hline
\end{tabular}

Source: [8] (analysis results).

There are several medicinal plant productions in Indonesia that are currently exported as a large foreign exchange earner because the demand in the global market tends to increase. In 2018, the most exported medicinal plants produced were ginger, turmeric and cardamom. The export volume of ginger was 3,203 tons or US\$ 3.65 million, the export volume of turmeric was 9,049 tons or 
US\$ 12.26 million, and the export volume of cardamom was 7,847 tons or US\$ 16.48 million. Main export destination country for ginger is Malaysia followed by India with export volumes of 1,019 tons and 504 tons, respectively [8].

Furthermore, processed products in the form of herbs medicines have high economic value due to the increasing demand in the global market, which is estimated to grow by $8.5 \%$ per year. In Indonesia, there are currently 11,000 traditional herbs remedies, 71 standardized herbs medicines, and 11 phyto-pharmacy [9]. From the aspect of herbs medicinal plants production or supply continues to grow and from the aspect of demand also continues to grow. According to the Indonesian Food and Drug
Administration (2020), herbs medicine occupies a large portion of the drugs trade. It is estimated that in 2022 the value will reach IDR 13.2 trillion or about US\$ 9.1 million and with a relatively stable average growth rate of 9.8\%/year. Furthermore, based on data from the Indonesian Ministry of Trade in the first semester of 2020, the export value of Indonesian biopharmaceutical products has reached US\$ 4.2 million, an increase of $32.8 \%$ compared to the same period in 2019 of US\$ 3.17 million [10]. The following is the export volume and value of several potential medicinal plant commodities in Indonesia, see Table 3.

Table 3. Production and Export Volume of Several Medicinal Plants in Indonesia

\begin{tabular}{|c|l|c|c|r|r|}
\hline Year & Commodities & $\begin{array}{c}\text { Harvest Area } \\
\text { (ha) }\end{array}$ & $\begin{array}{c}\text { Production } \\
\text { (ton) }\end{array}$ & $\begin{array}{c}\text { Export Volume } \\
\text { (ton) }\end{array}$ & $\begin{array}{c}\text { Export Value } \\
\text { FOB (US \$) }\end{array}$ \\
\hline \multirow{2}{*}{2015} & Ginger & 15,324 & 313,064 & 25,935 & $18,230,203$ \\
\cline { 2 - 6 } & Tumeric & 5,658 & 113,101 & 8,671 & $10,499,058$ \\
\cline { 2 - 5 } & Cardamon & 4,343 & 93,121 & 6,375 & $8,317,173$ \\
\hline \multirow{2}{*}{2016} & Ginger & 12,937 & 340,341 & 21,934 & $10,580,853$ \\
\cline { 2 - 6 } & Tumeric & 5,171 & 107,770 & 8,309 & $11,707,807$ \\
\cline { 2 - 6 } & Cardamon & 3,879 & 86,144 & 4,114 & $6,202,939$ \\
\hline \multirow{2}{*}{2017} & Ginger & 10,556 & 216,587 & 23,552 & $13,538,269$ \\
\cline { 2 - 6 } & Tumeric & 6,497 & 128,339 & 7,592 & $10,999,809$ \\
\cline { 2 - 6 } & Cardamon & 4,363 & 90,787 & 7,163 & $10,861,109$ \\
\hline \multirow{2}{*}{2018} & Ginger & 10,205 & 207,412 & 3,203 & $3,651,668$ \\
\cline { 2 - 6 } & Tumeric & 7,481 & 203,458 & 9,049 & $12,259,839$ \\
\cline { 2 - 6 } & Cardamon & 3,505 & 81,725 & 7,848 & $16,475,863$ \\
\hline
\end{tabular}

Source: [11-13], [8]

From Table 3, it can be seen that the production and export volumes of several medicinal plants have tended to increase. Thus, the prospect of developing this medicinal plant business is expected to be very bright to support the increase in community income, especially for medicinal plant farmers. However, in reality, there are still many problems in the field so that the development of medicinal plant cultivation is not as expected. Therefore, one of the things that needs to be done is to develop the Medicinal Plant Entrepreneurship to bridge the aspects of production or supply and downstream or aspects of demand so that these two aspects will synergize harmoniously with each other. To discuss further about the entrepreneurship role of this medicinal plant, it is necessary to know the trading system of medicinal plants.

\section{Trading of medicinal plants production}

The trading of medicinal plants production in Indonesia firstly from farmer is sold to collector traders who are small traders. These traders usually operate in areas not far from the location of medicinal plant farmers, where they interact with farmers all the time. Furthermore, the trade chain for the production of these medicinal plants from the Collecting Traders is sold to the Wholesaler and then sold to the herbs medicine industryIn general, the flow of trade in the production of medicinal plants is presented in Figure 3 below.

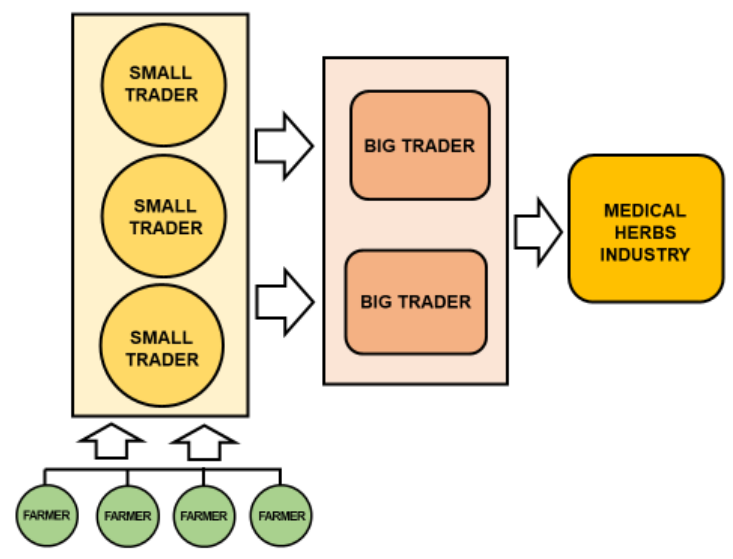

Figure 3. General Trade of Medicinal Plant Production

In general, these medicinal plant farmers have a low educational level, so: (a). There are still many farmers cultivate their medicinal plants traditionally, (b). Production materials especially in the form of superior 
seeds and fertilizers are still lacking. Therefore, in general the productivity and quality of medicinal plant production are low, so the selling price of medicinal plant production from farmers is also low. In fact, sometimes the herbs medicine industry cannot accept the production of medicinal plants from farmers. In addition, farmers in general also do not have access to information so their bargaining position in the market is very low.

To overcome this, it is necessary to build an entrepreneurship model, where this entrepreneur has a role to foster the Medicinal Plant Farmer Group so that the quality of medicinal plant production can meet the standards of the herbs medicine industry. It is hoped that the emergence of the medicinal plant production entrepreneurship will shorten the trade chain in the medicinal plant production system so that farmers will get a high selling price from the sale of their production.

\section{Entrepreneurship development model}

One of the efforts to develop entrepreneurship in the field of medicinal plants is by building a model for entrepreneurship development. In general, to achieve success in entrepreneurship coaching, it is necessary to increase the ability of entrepreneurs which carried out in business incubators. The role of business incubators in increasing entrepreneurship skills is shown in Figure 4 below.

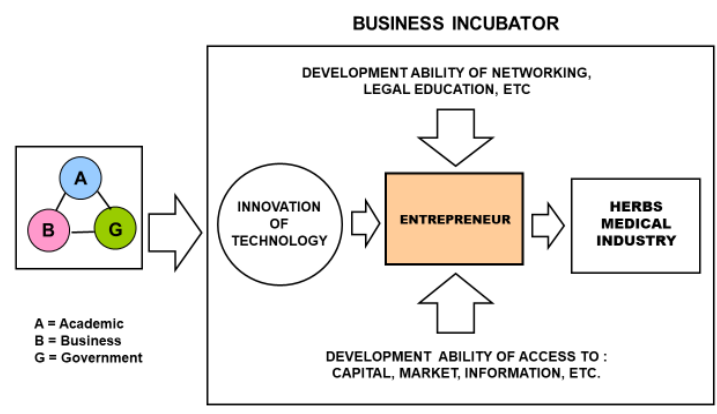

Figure 4. Model of Entrepreneurship Development in a Business Incubator

In Figure 4, it can be seen that in order to achieve success in the entrepreneurship development of medicinal plants, it is necessary to introduce technology, in this case various appropriate technologies. Most of these technological innovations are the result of innovations from Research and Development (R\&D) actors known as the Triple Helix, namely from Academic (Higher Education), Business (Industry) and Government (Government research institutions). This medicinal plant entrepreneurship development needs to be continuously developed in order to strengthen and fight for the interests of farmers and entrepreneurs in developing medicinal plant commodities. The entrepreneurship development carried out in this Business Incubator concerns various matters, especially those related to networking development, promotion of production, access to capital, legal aspects, and information technology. The emergence of these entrepreneurs is expected to be able to make partnerships with the herbs medicine industry and will even be able to export various kinds of medicinal plant production.

Therefore, the principle of fostering entrepreneurship in medicinal plants is carried out by creating mutually beneficial synergies for three main actors, namely: Farmers (as producers of medicinal plant commodities), Entrepreneur (as an actors who bridge between farmers and the herbs medicine industry), and Industry or herbs medicine industry(as buyers of medicinal plants production). Currently there is a synergy among the three main actors which is supported by PT Sido Muncul (herbs medicine industry)in several districts in Central Java. Until 2015, PT Sido Muncul through the role of entrepreneurship partners had provided coaching facilities for more than 100 farmer groups, especially in Karanganyar, Sukoharjo, Wonogiri, and Semarang Districts, Central Java. In addition PT Sido Muncul also provides facilitation in the form provision of superior seeds, cultivation assistance until harvest [14]. PT Sido Muncul will purchase allproduction of these medicinal plants from farmers at a high price.

In order to more strengthen for the synergy between the herbs medicine industry and medicinal plant farmers can be grow, so the efforts to develop these entrepreneurs model need to be continuously improved by implementing several strategies so that the synergy between the three main actors will getting stronger.

\section{Entrepreneurship development strategy}

In order to get performance optimally of the medicinal plant entrepreneurship, it is necessary to carry out an entrepreneurship coaching strategy which is described in Figure 5 below.

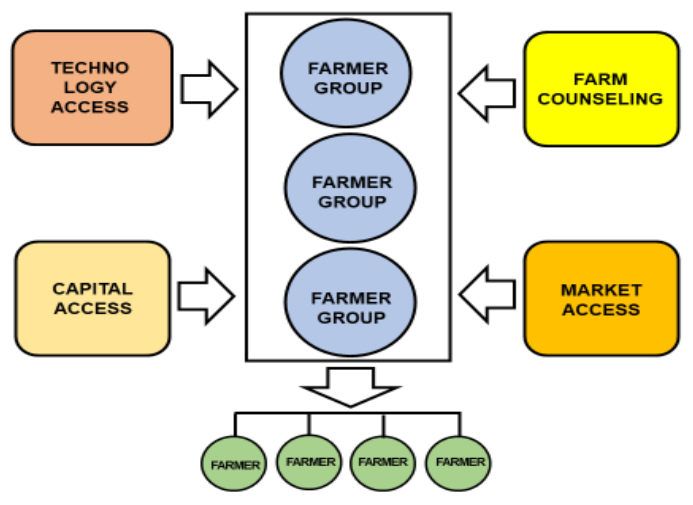

Figure 5. Herbs Medicinal PlantEntrepreneurship Development Strategy

In Figure 5, it can be seen that there are several strategies that must be taken in the development of this medicinal plant entrepreneurship to achieve success, namely: (a). Access to Technology. These medicinal plant entrepreneurs need to get facilitation, especially from the central or local government in the form of technology 
access [15]. In this business incubator, the entrepreneurs will be introduced to various technologies to support the implementation of their business. It is hoped that these entrepreneurs will educate farmers to produce medicinal plants where the production quality is in accordance with buyers' demand, in this case the herbs industrail medicine. With this access to technology, it is hoped that the farmers who are guided by these entrepreneurs will be able to increase the productivity and quality of medicinal plant production which is the core of production competitiveness, (b). Access to Business Capital. Medicinal plant entrepreneurs, including medicinal plant farmers, need to get facilitation from the government in the form of access to business capital, especially to purchase adequate production facilities through credit. Several provinces in Indonesia have stated that they are willing to guarantee this credit, such as the Provincial Governments of South Sumatra, South Kalimantan and South Sulawesi. In implementing this strategy, the central or local government can collaborate with several financial institutions, where entrepreneurs, especially novice entrepreneurs and medicinal plant farming communities, generally do not have sufficient business capital to develop their business. Therefore, it is also necessary to promote better cooperation between district governments, especially in medicinal plant cultivation centers, and banking institutions to be able to provide agricultural business loans with low interest rates, (c). Extension of Medicinal Plants Cultivation. The implementation of counseling for the development of medicinal plant cultivation can be carried out through fostering farmer groups, especially to help farmers to be willing and able to apply medicinal plant cultivation technology properly according to the principles of Good Agricultural Practices (GAP). It is hoped that the application of GAP will increase the productivity and quality of medicinal plant production, and (d). Market Access. These medicinal plant entrepreneurs need to get facilitation from the government in the form of market access [15]. Until now, there has not been much cooperation to develop the market for medicinal plant production. The local government in this case can support this market access which can be done through cooperation with several related parties such as the herbs medicine industry, the cosmetics industry, the food and beverage industry which uses raw materials from the production of medicinal plants, exporters for the production of medicinal plants, and others.

\section{CONCLUSION}

The emergence of these entrepreneurs is expected to have access to technology, capital and adequate information to be able to foster farmers so that the productivity and quality of medicinal plants will be higher and the trade chain will be shorter so that farmers will get increased income. The next expected impacts are: (a). triggering more farmers to participate in cultivating medicinal plants, (b). the competitiveness of medicinal plants production is increased, and (c). support government programs in community economic empowerment. To support the success of this, at the macro level the government needs to formulate policies from the upstream side (production of medicinal plants from farmers) which must be balanced with the downstream side (the need for raw materials for the herbs medicine industry). The existence of harmony between the upstream and downstream sides is expected to provide a balance between the production of medicinal plants and the need of raw materials in the herbs medicine industry on a national scale so that mutually beneficial and synergies will be well sustainable.

\section{REFERENCES}

[1] Badan Pengawas Obat dan Makanan, "Potensi Obat Herbal Indonesia", 2020, Accessed: July 15, 2020. [Online]. Available: https://www.pom.go.id/ new/view/more/pers/531/Potensi-Obat-HerbalIndonesia.html

[2] World Health Organization (WHO), "Double Burden Diseases", 2014, Accessed: July 13, 2020. [Online]. Available: http://www.who.int/nutrition/topics/2/_background/en /index1.html.

[3] Badan Pengkajian dan Penerapan Teknologi, “Outlook Teknologi Kesehatan 2016”, Jakarta, 2016.

[4] Departemen Pertanian, "Prospek dan Arah Pengembangan Agribisnis Tanaman Obat". Second Edition, Jakarta, 2007.

[5] Kementerian Kesehatan. "Surat Keputusan Menteri Kesehatan No.381/Menkes/SK/III/2007”, 2007, Accessed: Aug 10, 2020. [Online]. Available: https://peraturan.bkpm.go.id/jdih/userfiles/ batang/KEPMENKES_381_2007.pdf

[6] S. Siahaan., and N. K. Aryastami, "Studi kebijakan pengembangan tanaman obat di Indonesia". Media Litbangkes, Vol. 28 No. 3, pp. 157-166, 2018.

[7] B. Pujiasmanto, "Strategi Pengembangan Budidaya Tumbuhan Obat Dalam Menunjang Pertanian Berkelanjutan”. Orasi Ilmiah Pengkukuhan Guru Besar Ilmu Pertanian', Universitas Sebelas Maret, Surakarta, 2016.

[8] Badan Pusat Statistik, "Statistik Tanaman Biofarmaka 2018”, Jakarta, 2019.

[9] M. Andarini, "Standardisasi obat herbal dan tantangan dalam masa pandemi covid-19", Jakarta, 2020.

[10] Kontan, "Menggaet peluang di tengah pandemi, Sido Muncul ekspor perdana obat herbal ke Arab Saudi", 2020, Accessed: Aug 11, 2020. [Online]. Available: https://industri.kontan.co.id/ news/menggaetpeluang-di-tengah-pandemi-sido-muncul-eksporperdana-obat herbal-ke-arab-saudi

[11] Badan Pusat Statistik. "Statistik Tanaman Biofarmaka 2015”, Jakarta, 2016.

[12] Badan Pusat Statistik, "Statistik Tanaman Biofarmaka 2016", Jakarta, 2017.

[13] Badan Pusat Statistik, Statistik Tanaman Biofarmaka 2017, Jakarta, 2018. 
[14] F. Sodiq, "Gandeng Petani, Sido Muncul Pastikan Serap Tanaman obat Obat herbal”, 2015, Accessed: June 15, 2020. [Online]. Available: https://www.viva.co.id/arsip/608795-gandeng-petanisido-muncul-pastikan-serap-bahan-baku-obat herbal
[15] D. Mulyono, "Pembinaan Wirausaha Kopi di Science and Technopark (STP) Pondok Pusaka, Kabupaten Kaur, Bengkulu”, 2016. 